\title{
Influence of Demographic Variables on Alcohol Intake and Abuse in Owerri Municipal Council: Counseling Implications
}

\author{
Dr. (mrs.) Rosemary Ekechukwu \\ Department of Educational Psychology, Guidance and Counseling, University of Port Harcourt \\ mamatriplets01@yahoo.com \\ Ogu Cyprian I. \\ Department of Educational Psychology, Guidance and Counseling, University of Port Harcourt
}

\begin{abstract}
The study investigated the influence of demographic variables on alcohol intake and abuse in Owerri municipal council of Imo State, Nigeria. A sample of 160 respondents were purposively selected from an estimated population of 127,000. Five research question and correspond hypotheses were answered and analysed respectively using mean, standard deviation and t-test. The result of the finding showed that age, gender and marital status influenced alcohol intake and abuse while educational qualifications and occupation did not have any significant influence on alcohol intake and abuse among the people of Owerri municipal council. Based on the result of the findings conclusion and recommendation were made, one of which is that all the stakeholder especially the local government council should monitor the indiscrimination sale and distribution of alcohol and other substances. Also illegal citing of bush bars and motels should be checked.
\end{abstract}

\section{INTRODUCTION}

The rate at which alcohol is consumed in Owerri municipal council and its environs has assumed an alarming level. This is evidenced in the increased number of hotels and other businesses that engage in the sale and distribution of alcoholic drinks and beverages which has lead to an increased level of alcohol intake and abuse.

This very scenario has become a thing of concern to the researcher hence the need to carry out this research to ascertain what are the remote causes of this habit. In Owerri municipal council, there are about 217 registered hotels and about 180 unregistered bush bars and motels (Police report December, 2015).

Alcohol is the central name for all kinds of depressants, liquors and beverages both the locally distilled and the industrial products. It is regarded as a drug because it has all the qualities of a drug for instance, when it is consumed in large quantities, it significantly depresses the user and alters his/her mental state. Alcohol products found in Nigeria are the local gin (Ogogoro, Akamere, Kaikai, Manya-oku, ukwu-elu) Pito, Burukutu, palm wine, whisky, beer brandy, wine and others. In Nigeria alcohol is the most commonly used and abused drug because the law allows it to be used freely by people. More so, it is quite available and less expensive compared with other substance s. (Onungine, 2015)

Heavy alcohol intake even on a single occasion, can result to harm for another individual other than the individual consuming it, for example, through foetal alcohol syndrome(FAS), a mother can harm the unborn child by just a single occasion of alcohol intake (Aulti-Ramo, 2000), in the case of violent or abusive behaviour an intoxicated individual can rape, fight, engage in armed robbery and assault (Maestro, Galizio and Cannors, 2004).

The effects of chromic high use of alcohol includes, damage to the mouth, esophagus, digestive organs, liver, pancreas, heart, kidney and brain. (National Health and Medical Research Council 2001, Ekeke 2014)

Alcohol intake and abuse in Owerri municipal council may likely be attributed to the life style of the indigenes that has equally influenced the visitors. A popular saying in Owerri is this. 'if I eat African 
Salad (Ukpa) and drink alcohol, am alright, those who are laboring to be wealthy should go ahead". The researcher is interested in finding out the factors that has contributed to this culture of excessive drinking by both young and old in Owerri municipal council area. Demographic variables such as age, gender, educational qualification marital status and occupation were identified as factors influencing alcohol intake and abuse in Owerri municipal council.

Alcohol abuse is the habitual excessive use of alcohol. (Google 2015). There are two types of alcohol abuse. There are those who have anti-social and pleasure seeking tendencies and those who are anxiety - ridden people who are able to go without drinking for a long period of time but are unable to control themselves once they start. (Wikipedia 2015). Binge drinking is another form of alcohol abuse. Binge drinking or heavy episodic drinking is a modern epithet for drinking alcoholic beverages with the primary intention of becoming intoxicated by heavy consumption of alcohol over a short period of time.

Public health experts and psychologists are in agreement that the environment in which people live and work heavily influence their attitude and behaviours as well as intake and abuse of alcohol. Environmental influences on alcohol use include; acceptance of alcohol use by the society, availability, advertising and marketing both nationally, locally and public policies regarding alcohol and enforcement of those policies (Onungine, 2015).

\section{Statement of Problem}

The issue of alcohol intake and abuse has become a common phenomenon in Owerri Municipal council area as there is remarkable increase in the number of places where such alcoholic drinks are sold. Alcohol like most drugs has power to make those who drink it to become addicted, Individuals addicted develop a strong drive, need or compulsion to continue taking the substance, and develops tolerance, that is, a tendency to increase the dose and development of physical and emotional dependence which results in altered psychological state.

Alcohol as a central neurous depressant and as a sedative hypnotic produces relaxation effects at low doses and sleep at high doses. As a depressant, alcohol blocks inhibitor neurons more effectively than excitatory neurons. The consequence of such doses is a reduction of anxiety and deceptive self consciousness, a pleasurable loss of inhibitory control and an enhance sense of efficacy, excessive intake of the substance may equally lead to the development of anxiety, restlessness and feedings of tension, profuse sweating runny nose and eyes dilation of the pupils trembling, diarrhea and cramps. All these symptoms are problems faced by both men and women who abuse alcki [ohol. The crux of this study is therefore to find out those factors that influence the excessive intake and abuse of alcohol in Owerri municipal council area. To the best of the researcher's knowledge no work has been carried out in this area with the variables used in the study.

\section{PuRPOSE OF THE STUdY}

The purpose of the study in specific terms, were to.

Find out the influence of age, gender, educational qualification, marital status and occupation on alcohol intake and abuse in Owerri municipal council area.

\section{SigNificance OF THE STUdY}

The study will serve as a reference point for academic purposes to subsequent researchers including students, teachers and organizations. The study will be of great benefits to students, parents, teachers, guidance counselors, social workers and local government authorities, this is because the result of the study will help all the above mentioned stakeholders to intensify their campaign against excessive alcohol intake and abuse.

The study will help reduce the prevalence rate of excessive alcohol intake and abuse in Owerri municipal council area. The study will help the council authorities to monitor the sale of alcohol to people. They will also use this study to institute incensing of beer parlors instead of the indiscriminate opening of drinking houses all over the area.

Parents who have the concern of their children at heart should take drastic measures to ensure that their children do not become prone to excessive alcohol intake and abuse through the available recommendation and suggestions that are made available in the study. 


\section{SCOPE OF THE STUDY}

The study focused on excessive alcohol intake and abuse which is the dependent variable, while demographic variable, such as age, gender, educational qualification marital status and occupation were the independent variables.

These variables were selected for the study because little or no attention has been given to them by previous researchers as it relates to alcohol intake and abuse in Owerri municipal council area.

\section{RESEARCH QUESTIONS}

1. What is the influence of age on alcohol intake and abuse in Owerri municipal council area.

2. What is the influence of gender on alcohol intake and abuse in Owerri municipal council area.

3. What is the influence of educational qualification on alcohol intake and abuse in Owerri municipal council area.

4. What is the influence of marital status on alcohol intake and abuse in Owerri municipal council area.

5. What is the influence of occupation on alcohol intake and abuse in owerri municipal council area.

\section{HYPOTHESES}

The following Null Hypotheses were tested at 0.05 level of Significance.

1. There is no significant influence of age on alcohol intake and abuse in Owerri municipal council area.

2. There is no significant influence of gender on alcohol intake and abuse in Owerri municipal council area.

3. There is no significant influence of educational qualification on alcohol intake and abuse in Owerri municipal council area.

4. There is no significant influence of marital status on alcohol intake and abuse in Owerri municipal council area.

5. There is no significant influence of acceptation on alcohol intake and abuse in Owerri municipal council area.

\section{Methodology}

The study adopted ex-post facto research design. Kpolovie (2010: ), stated that ex-post facto research is used to cover in retrospectively that which are done retrospectively (after the effect has occurred) to identify possible cause and effect relationship between the variables under study through observations of existing conditions.

The researcher chose ex-post facto design because, it involves a methodological approach for eliciting possible or probable antecedents of events that have occurred already (alcohol intake and abuse 0 and which cannot be subjected to the direct rigorous manipulation and control of the researcher. The researcher also chose this design because of ethical considerations preventing the researcher from manipulation of the variables under study.

\section{Population OF THE STUdy}

The population of the study comprised all the inhabitants of Owerri municipal council area. The estimated population is about 127,000 people (2005 census). This population resides in the capital city of Imo State (Heart land). The researcher decided to use this population because the capital city house many hotels, beer parlors, motels and other shops that sell and distribute alcohol which indeed has influenced their life style of drinking alcoholic drinks and beverages.

\section{SAMPLE AND SAMPLING TeChNIQUES}

The sample for the study composed purposively of 160 respondents because of the time frame of this study. 


\section{AREA OF THE STUDY}

The study was carried out in Owerri municipal council area of Imo state. Owerri municipal is a Local Government Area of Imo state, Nigeria, its head quarter is in the city of Owerri. Owerri municipal council was formerly the head quarters of old Owerri Local Government Area (comprising present day Owerri municipal, Owerri North, Owerri West and Ngor-Okpala L.G.A.). It became a municipal council on $15^{\text {th }}$ December 1996.

It is the capital city of Imo state, the eastern Heartland, and as such the landlord to most Government Ministries, Departments and Agencies (both state and Federal), historically the Indigenes of Owerri municipal council are descendants father, who bolted from his ancestral home of URATTA around 1463 to settle at "UGWU EKWEMA" and became the founding father of "OWERRE"

The council has an urban setting with one autonomous community made up of 5 indigenous kindreds (Owerre Nchi ise)

Vis; Umuororonjo, Amawom, Umuonyeche, Umuochi and umuogima, under the rulership of one paramount traditional ruler, presently Eze Dr. Emmanuel Emenyeonu Njemanze Ozuruigbo V. is the paramount ruler. The apex traditional institution in the area is the "Oha Owerre" Elders council, which is also the judicial arm of government settling all disputes and other matters). Onye Ishi ala Owerre "is the traditional chief priest of the community. The entire women of "Owerre Nche ise" are also under one umberella body - The 'Udodiri Ndom.

Entrances into the municipal council are Okigine Road, Onistsha Road, Port Harcourt Road, Aba Road and Mbaise Road respectively solid mineral deposits abound all over the council area such as Phosphate, Limestone, Kaolin, galena, stones and granites, silica sand etc. the council is also blessed with agricultural products like cassava, yam, maize, livestock, fruits.

Many business and investment opportunities exist in the municipal council because of the vantage position, the council occupies as the seat of Government and therefore the epicenter $f$ all economic, social, religions activities in the state.

The hospitality industry is ever on the rise, educational services, information technology services, small scale industries such as agro allied and food processing fashion and beauty industry, transportation consiness (intercity/intercity), Banking and financial sector, fast food and eatery as well as hotels and drinking houses are found all over the capital city of Owerri municipal council.

The present chairman of the Owerri municipal L.G.A is Hon Jonathan Amukam T.C. Owerri municipal council is the melting point of culture and tradition. ORU OWERRE historical cultural festival takes place in it every year. Ofe Owerri or of (Owerre) is a staple soup extra gently prepared during the festival. It is a month-watering and finger-licking song cooked and enjoyed by people from Imo State, particularly Owerri municipal council indigenes. The soup is so much valued that there is a popular saying "He who does not have money cannot eat Ofe Owerre, also he who has no money cannot marry Owerre girl since she will prepare ofe owerri" "No money No ofe owerre, No, Owerre girl".

\section{DEVELOPMENT OF THE INSTRUMENT}

The instrument for the study is the alcohol intake and abuse inventory (AIBI). It was a non-cognitive instrument. The instrument was developed through the logical method. This method involved the researcher writing out a large pool of questions focusing on alcohol in take and abuse. Some of the items of the instruments were positively keyed while others were negatively keyed. It had two sections, section A consisted the demographic variables of age, gender, educational qualification, marital status and occupation while section B contained the questions (items) on alcohol intake and abuse. The items were constructed along a four points modified likert scale of (SA) Strongly Agree (A) Agree, (D) Disagree and (SD) Strongly Disagree.

\section{VALIDITY OF THE INSTRUMENT}

Face, content and construct validity of the instrument (A1B1) was well determined by experts in psychometrics. 
Influence of Demographic Variables on Alcohol Intake and Abuse in Owerri Municipal Council: Counseling Implications

\section{RELIABILITY OF THE INSTRUMENT}

The reliability of the "Alcohol intake and abused inventory (A1B1) was determined through the use of test-re-test method for a measure of consistency. The result got through the use of Pearson moment correlational coefficient was 0.65 . This coefficient was very reliable for the items to be used in this study.

\section{DATA ANALYSiS}

\section{Research Question One}

What is the influence of age on alcohol intake and abuse in Owerri Municipal Council area?

\section{Hypothesis One}

There is no significant influence of age on alcohol intake and abuse in Owerri Municipal Area

Table1a. Descriptive statistics on the influence of age on alcohol intake and abuse

\begin{tabular}{|l|l|l|l|}
\hline & N & Mean & Std. Deviation \\
\hline eighteen to thirty years & 22 & 65.9091 & 10.02810 \\
\hline thirty to forty & 52 & 69.8654 & 6.70390 \\
\hline forty and above & 86 & 72.4651 & 4.98869 \\
\hline Total & 160 & 70.7188 & 6.78898 \\
\hline
\end{tabular}

Table1b. One Way Analysis of Variance on the Influence of Age on Alcohol Intake and Abuse

\begin{tabular}{|l|l|l|l|l|l|}
\hline & Sum of Squares & df & Mean Square & F & Sig. \\
\hline Between Groups & 809.073 & 2 & 404.536 & 9.742 & .000 \\
\hline Within Groups & 6519.271 & 157 & 41.524 & & \\
\hline Total & 7328.344 & 159 & & & \\
\hline
\end{tabular}

Table 1a answers the research question. It revealed that ages from forty and above (40-above) has the highest mean of 72.4651 with standard deviation score of 4.98869 therefore influences alcohol intake and abuse, followed by thirty to forty (30-40years) with mean and standard deviation score of 69.8654 and 6.70390 , and finally by eighteen to thirty years (18-30years). Table $1 \mathrm{~b}$ answered the hypothesis posed at 0.05 alpha level. The table shows that between groups have sum of square of 809.073, within groups also have sum of square of 6519.271 . The degree freedom is given thus $(2,157)$, mean squares 404.536 and $41.524, F=9.742$ and $p>0.00$. The null hypothesis is rejected. There is a significant influence of age on alcohol intake and abuse in Owerri Municipal Area. Multiple comparis on shows that the mean of the variables are significant with each other in influencing alcohol intake and abuse.

\section{Research Question Two}

What is the influence of gender on alcohol intake and abuse in Owerri Municipal Council Area?

\section{Hypothesis Two}

There is no significant influence of gender on alcohol intake and abuse in Owerri Municipal Council Area.

Table2.Mean, Standard Deviation and t-Test Statistics of influence of Gender on Alcohol Intake and Abuse in Owerri Municipal Council Area

\begin{tabular}{|l|l|l|l|l|l|l|}
\hline Category & N & mean & Std. & Df & T & Sig. \\
\hline Female & 105 & 69.4952 & 7.49631 & 153 & 3.243 & .001 \\
\hline Male & 55 & 73.0545 & 4.36068 & & & \\
\hline
\end{tabular}

Table 2 shows that male respondents have more on alcohol intake and abuse than their female counterparts. The mean and standard deviation of female respondents are 69.4952 and 7.49631 while that of male respondents are 73.0545 and 4.36068 respectively. $\mathrm{Df}=153, \mathrm{t}=3.243, \mathrm{p}>0.001$. The null hypothesis is rejected. By implication, there is a significant influence of gender on alcohol intake and abuse in Owerri Municipal Council Area.

\section{Research Question Three}

What is the influence of educational qualification on alcohol intake and abuse in Owerri Municipal Council Area? 


\section{Hypothesis Three}

There is no significant influence of educational qualification on alcohol intake and abuse in Owerri Municipal Council Area.

Table3a.Descriptive Statistics of the Influence of Educational Qualification on Alcohol Intake and Abuse

\begin{tabular}{|l|l|l|l|}
\hline & N & Mean & Std. Deviation \\
\hline tertiary & 35 & 66.1714 & 8.49043 \\
\hline secondary & 28 & 68.8214 & 6.73330 \\
\hline primary & 79 & 72.7468 & 5.15271 \\
\hline none & 18 & 73.6111 & 4.07487 \\
\hline Total & 160 & 70.7188 & 6.78898 \\
\hline
\end{tabular}

Table3b.One Way Analysis of Variance of the Influence of Educational Qualification on Alcohol Intake and Abuse

\begin{tabular}{|l|l|l|l|l|l|}
\hline & Sum of Squares & df & Mean Square & F & Sig. \\
\hline Between Groups & 1300.051 & 3 & 433.350 & 11.214 & .000 \\
\hline Within Groups & 6028.293 & 156 & 38.643 & & \\
\hline Total & 7328.344 & 159 & & & \\
\hline
\end{tabular}

Table 3a shows that those who did not attend school at all have the highest mean value of 73.6111 and standard deviation score of 4.07487, followed by primary school attendant with mean and standard deviation scores of 72.7468 and 5.15271, then secondary school attendants with mean and standard deviation scores of 68.8214 and 6.73330 and finally tertiary school attendants with mean and standard deviation scores of 66.1714 and 8.49043 respectively. Df $(3,156), F=11.214$ and $p>0.000$. Therefore the null hypothesis is rejected. By implication, there is a significant influence of educational qualification on alcohol intake and abuse in Owerri Municipal Council Area. Mean comparison shows that they significant to each other in influencing alcohol intake and abuse.

\section{Research Question Four}

What is the influence of marital status on alcohol intake and abuse in Owerri Municipal Council Area.

Table4a.Descriptive Statistics on the Influence of Marital status on Alcohol Intake Abuse in Owerri Municipal Council Area.

\begin{tabular}{|l|l|l|l|}
\hline & N & Mean & Std. Deviation \\
\hline Single & 66 & 67.6061 & 7.75962 \\
\hline Married & 25 & 73.3200 & 5.91411 \\
\hline Widower & 29 & 73.4483 & 4.50068 \\
\hline Widow & 17 & 70.1765 & 5.01542 \\
\hline Divorced & 17 & 74.7647 & 3.17272 \\
\hline Separated & 6 & 71.0000 & 5.21536 \\
\hline Total & 160 & 70.7188 & 6.78898 \\
\hline
\end{tabular}

Table4b.One Way Analysis of Variance on the Influence of Marital Status on Alcohol intake and Abuse

\begin{tabular}{|l|l|l|l|l|l|}
\hline & Sum of Squares & df & Mean Square & F & Sig. \\
\hline Between Groups & 1308.444 & 5 & 261.689 & 6.694 & .000 \\
\hline Within Groups & 6019.899 & 154 & 39.090 & & \\
\hline Total & 7328.344 & 159 & & & \\
\hline
\end{tabular}

Table $4 \mathrm{a}$ provided answer to the descriptive statistics. It appears that divorced has the highest mean value of 74.7647 and standard deviation score of 3.17272 and influenced more alcohol intake and abuse followed by widower with mean and standard deviation scores of 73.4483 and 4.50068 , married with mean and standard deviation scores of 73.3200 and 5.91411, separated with mean value of 71.0000 and standard deviation scores of 5.21536 and finally, single with mean and standard deviation scores of 67.6061 and 7.75962. df $(5,154), F=6.694$ and $p>0.001$. The null hypothesis is rejected. By conclusion, there is a significant influence of marital status on alcohol intake and abuse in Owerri Municipal Area. Multiple comparison shows significant influence between the means.

\section{Research Question Five}

What is the influence of occupation on alcohol intake and abuse in Owerri Municipal Council Area? 
Influence of Demographic Variables on Alcohol Intake and Abuse in Owerri Municipal Council: Counseling Implications

\section{Hypothesis Five}

There is no significant influence of occupation on alcohol intake and abuse in Owerri Municipal Council Area.

Table5a.Descriptive Statistics on the Influence of Occupation on Alcohol Intake and Abuse in Owerri Municipal Area.

\begin{tabular}{|l|l|l|l|}
\hline & N & Mean & Std. Deviation \\
\hline Student & 20 & 65.1500 & 10.06440 \\
\hline Trader & 36 & 68.0278 & 6.71240 \\
\hline Labourer & 65 & 73.0769 & 5.06306 \\
\hline civil servant & 39 & 72.1282 & 4.77482 \\
\hline Total & 160 & 70.7188 & 6.78898 \\
\hline
\end{tabular}

Table5b.One Way Analysis of Variance on the Influence of Occupation on Alcohol Intake and abuse

\begin{tabular}{|l|l|l|l|l|l|}
\hline & Sum of Squares & df & Mean Square & F & Sig. \\
\hline Between Groups & 1319.847 & 3 & 439.949 & 11.423 & .000 \\
\hline Within Groups & 6008.497 & 156 & 38.516 & & \\
\hline Total & 7328.344 & 159 & & & \\
\hline
\end{tabular}

Table 5a revealed that labourers influence alcohol intake and abuse more with the highest mean value of 73.0769 and standard deviation score of 5.06306, followed by civil servants with mean and standard deviation scores of 72.1282 and 4.77482 , then traders with mean and standard deviation scores of 65.1500 and 10.06440 and finally, by students with mean and standard deviation scores of 65.1500 and 10.06440 respectively. $\operatorname{Df}(3,156), \mathrm{F}=11.423$, and $\mathrm{p}>0.001$. The null hypothesis is rejected. By implication, there is a significant influence of occupation on alcohol intake and abuse in Owerri Municipal Council Area. Multiple comparisons shows a significant influence between the means of the variables on alcohol intake and abuse

\section{SUMMARY OF FINDINGS}

The findings of this study are as summarized as shown below:

1. There is no significant influence of age on alcohol intake and abuse in Owerri Municipal Area.

2. There is a significant influence of gender on alcohol intake and abuse in Owerri Municipal Council Area.

3. Therefore the null hypothesis is rejected. By implication, there is a significant influence of educational qualification on alcohol intake and abuse in Owerri Municipal Council Area.

4. The null hypothesis is rejected. By conclusion, there is a significant influence of marital status on alcohol intake and abuse in Owerri Municipal Area.

5. There is a significant influence of occupation on alcohol intake and abuse in Owerri Municipal Council Area.

\section{DISCUSSION OF FINDINGS}

Age and alcohol intake and abuse in Owerri municipal council Area.

The findings revealed that age has influence on the intake and abuse of alcohol. A close look or check to the spots alcohol are sold and consumed reveals that, young adults and full blown adults patronesses the spots more than adolescents except in the campuses of higher learning (terrains institution).

The findings of the present study is agreement with that of Eneh and Stanly (2004) who found out that the mean age of alcohol use was about 22 years. They also found out that peer pressure also influenced the intake of alcohol by adolescents who wants to conform to their age norms. Peer pressure is commonly associated with episodes of adolescent risk taking (delinquency, drug abuse, sexual behaviours, excessive intake of alcohol etc) because these activities commonly occur in the company of peers (Lawrence, 2007). Ekeke (2014) also found out that peers influenced alcohol initiation of students in tertiary institutions. The present study is also an eye opener to the fact that adolescents from homes where alcohol are consumed heavily by their adult parents and significant others will eventually develop heavy drinking of alcohol and abuse of other substances. 


\subsection{Gender and Alcohol Intake and Abuse in Owerri Municipal Council Area}

Gender was found to influence intake and abuse of alcohol. This result was expected because a visit to the drinking spots reveal that those who are there are usually paired (male/female). Hardly you see only men drinking in beer parlours without their female counterparts. The present findings is in agreement with that of Perkins (2015) who observed from public response little or no gender differences in alcohol and other substance abuse. This is further buttressed by the fact that people drink to socialize, celebrate and relax with opposite sex (Ekeke, 2014).

\subsection{Educational Qualification on Alcohol Intake and Abuse in Owerri Municipal Council}

The findings here show that educational qualification does not influence alcohol intake and abuse. A person's educational status cannot determine how he will take and abuse alcohol or other substances. This result was expected because both educated, semi educated and illiterate male and female take and abuse alcohol without reference to their educational qualification or status. The present findings of the study is not in agreement with the findings of Huerta and Borgonovi, (2010), who found out that educational attainment is associated with increased daily alcohol consumption among females but low among male when they carried out their study among young adults in Britain.

\subsection{Marital Status Influence on Alcohol Intake and Abuse in Owerri Municipal Council Area}

A significant influence of marital status on alcohol intake and abuse was found. A walk down to drinking spots reveals that majority of those who patronize the spots are single men and women or married men who may be having challenges in their marital relationships or divorced who now find solace in drinking. The study is in agreement with Prescott, (2006), who found significant group differences in consumption of alcohol between different marital status. Their work showed that divorced women consumed more alcohol than women who stayed in marriage. The study also revealed that heavy drinking accompanys the transition from singlehood to marriage and that after marriage, an obvious decline in drinking was noticed, meaning that single people consume more alcohol than married people since to them is a form of socialization. A typical Owerri single lady or single male adult socialize regularly in drinking houses with their popular "Bongo" music. This is also to buttress their usual slogan that after drinking alcohol and eating of African salad (Ukpa) they are satisfied, those looking for riches should go ahead and labour".

\subsection{Occupational Influence on Alcohol Intake and Abuse in Owerri Municipal Council Area}

The findings revealed no significant influence of occupation on alcohol intake and abuse. The type of job an individual is engaged in, does not give him or her an impetus to overindulge in drinking alcohol. This result was not expected because it is expected that certain occupations predisposes an individual to indulge in heavy drinking of alcohol. For example seamen, bar attendants and politicians may likely be exposed to drinking alcohol more than other occupations. The finding of the present study is not in agreement with the work of Michael, Russel and Cooper, (2006), who observed that work - family conflict was positively related to abusive alcohol consumption when they carried out their research with about 473 employed adults. Crum, (2006) also found a significant relationship between high strain occupation and alcohol abuse which is also at variance with the present study. One's occupation hence does not predict whether he/she will abuse alcohol especially in Owerri Municipal Council Area.

\section{Conclusion}

The result of this study indicates that demographic variables such as age, gender and marital status influence alcohol intake and abuse. Therefore relevant agencies should put up measures in place to monitor the sale, distribution and consumption of alcohol so that it does not lead to abuse and more deaths in the Local Government. Proper licensing of sale of liquor and citing of beer parlours all over the city should be check-mated to preserve the lives of our young adults, singles and marriages.

\section{RECOMMENDATIONS}

In view of the finding, the following recommendations were made:-

1. The Local Government Council should organize programmes that will educate the masses on the adverse effect of excessive intake and abuse of alcohol.

2. The council should employ or set up monitoring teams who will ensure proper licensing and permit for alcohol sale and distribution and opening of beer parlours and hotels in and around the city 
3. Tax and levies for beer parlour operators should be increased so that the business will become less attractive and profitable to discourage new persons who may want to erect new ones.

4. Heavy campaign should be mounted by health management boards on the damaging effects of excess intake and abuse of alcoholic beverages.

5. The new trend of hawking alcoholic beverages on the highways and road sides in the city should be check-mated because many drivers may get drunk while on the steering and even innocent passersby or pedestrians may be hurt by them.

6. Binge drinking of alcohol and other substances should be discouraged especially in our high institutions. Also citing of beer parlours and eatery that serve liquors near secondary schools should be discouraged.

7. Seminars and workshops should be held for civil servants, students, artisans and pregnant women in order to preserve lives especially the unborn children in the womb.

\section{REFERENCES}

Autti - Ramo, I. (2001), Twelve year follow-up of children exposed to alcohol in uterus. Development,Medicine and Child Neurology. 42, $406-411$.

Ekeke, M.I. (2014), Psychological and Sociological factors as correlates of Alcohol Initiation Among University undergraduates. Unpublished M.ED Thesis. Department of Educational Psychology Guidance and Counselling, University of Port Harcourt.

Eneh, A.U. \& Stanley, P.C., (2004), Patterns of Substance Abuse Among Secondary School Students in Rivers State. Nigerian Journal of Medicine 13 (1), Retrieved on July $20^{\text {th }} 2015$ from www.medicinenigeria.com/journals/pat...

Kpolovie, P.J. (2010), Advanced Research Methods, Springfield Publisher Ltd.

Maistro, S.A. Galizio, M. \& Connors G.J. (2004), Drug use and abuse (4 ${ }^{\text {th }}$. Ed) C.A. Sage Publications.

Mckee, M. (2000), Alcohol Consumption in the Battic Republics, Journal of Epidemiology and Community Health. 34. $361-366$.

Michael, R.F., Marcia, R. \& Cooper, M.L. (2006). Relationshipof work family conflict, gender and alcohol expectancies to alcohol use/abuse". Journal of organization Behaviour, 14 (6) 545 - 558. Retrieved in August 2015 from www.wileyonlinelibrary.com.

Mills, K.C. and McCarthy D. (1983), A data based alcohol abuse prevention programme in a University setting. Journal of Alcohol and Drug Education 28 (2) 15 - 27.

Onungwe, G.O. (2015), Influence of Demographic variables on Alcohol Intake and Abuse in Eleme L.G.A of Rivers State. Unpublished B.ED Research work, Faculty of Education. University of Port Harcourt.

Owerri - Heartland, Owerri Municipal Council. Retrieved December 2015, http//www.mimostate. gov.ng/

Perkins, H.W. (2015), "Gender Patterns in Consequences of Collegiate, alcohol abuse, a 10 years study of trends in an undergraduate populations. Journal of studies on alcohol and drugs, (53), $458-462$.

Population and History of Owerri. Retrieved from Wikipedia, the free encyclopedia. http://www.citypopulation.de/php/Nigeria.

Prescott, C.A., Aggen, S.H. \& Kindler, K.S. (2006), Sex Differences in the sources of genetic liability to alcohol abuse and dependent in a population-based sample of U.S twins. Alcoholism: Clinical and Experimental research, 23 (7). Retrieved from www.wileyonlinelibrary.com

Thundal, K. (1999), Women alcohol dependence and abuse. The relation to social network and leisure time. Scandivian Journal of Public Health. 27. 30 - 37. 


\section{AUTHORS' BIOGRAPHY}

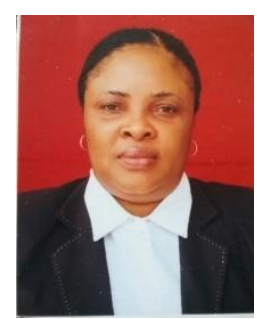

Dr Mrs Rosemary Ekechukwu, (Senior lecturer department of counseling psychology). Areas of interest, adolescent, marriage and addiction counseling Lectures at the University of Portharcourt.

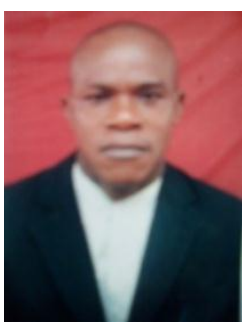

Fr. Cyprian Ogu, (Counseling psychologist).Areas of interest: Adolescent/marriage Counselor. Counseling of ageing people. Alcohol/druglabuse.

cypikogu@ya hoo.com 